\title{
Alkuvoimaista tunnetta
}

\author{
Riikka Rossi: Alkukantaisuusja tunteet: Primitivismi 1900-luvun alun suomalaisessa \\ kirjallisuudessa. Suomalaisen Kirjallisuuden Seuran Toimituksia 1456. Helsinki: SKS, \\ 2020, 264 S.
}

Riikka Rossin ehyt ja taiten kirjoitettu monografia on hyppy suomenkielisen kirjallisuuden kaanonin klassikoiden syvempiin kerroksiin. Alkukantaisuus ja tunteet käsittelee ytimekkään alaotsikkonsa mukaisesti sadan vuoden takaisia kirjallisia teoksia niin sanotun primitivismin eli edistysuskon ja "modernin" kritiikin värittämän historiallisen kirjallisuuskäsityksen kautta. Rossi tulkitsee primitivismiä sekä taiteen ja tieteen ilmiönä että aatehistoriallisena hybridinä, joissa kaikissa toistuu tavalla tai toisella kaipuu "myyttisen alkuperään", "aitouteen" tai "nostalgiseen luontoon". Rossin aineistoina ovat Joel Lehtosen, Juhani Ahon, Maria Jotunin ja F.E. Sillanpään kansallisesti esikuvallisen aseman saaneet tekstit, ja Rossi avaa näihin uusia näkymiä affektiivisten eli tunteisiin liittyvien ulottuvuuksien kautta.

Rossin kirjoitustyyli on värikäs muttei liian rönsyilevä: paikoin teoksen lukeminen on yhtä vetävää kuin kirjassa analysoitujen klassikoiden - ellei jopa vetävämpääkin. Luin Rossin tutkimuksen kesäkuun helteiden nuokahduttamassa kaupungissa, enkä voinut olla hieman tunnelmoimatta kirjan aiheeseen sopivaan nostalgisoivaan tyyliin tutkimuksen kieltä, muotoa ja jopa materiaalista olemusta. Miten hienoa onkaan - viimeisen vuosikymmenen aikana tapahtuneen, englanninkielistyneen ja artikkelistuneen akateemisen julkaisukulttuurin muutoksen jälkeen - pidellä käsissään suomenkielistä, vastajulkaistua tieteellistä kirjaa! Rossin monografia on juuri sellainen kuin sen pitääkin olla: tasapainoinen, syvällisesti aineistojaan luotaava, monipuolinen ja rikas.

Rossi on rakentanut analyysinsa ensisijaisesti erilaisten affektiivisten käsitteiden kuten kiukun, häpeän, pelon, rakkauden, hurmoksen ja inhon varaan. Tutkimus etenee tunne kerrallaan, eikä sen rakenteessa niinkään painotu teosten käyminen läpi jonomaisessa järjestyksessä. Pääosin Rossi onnistuu etenemään sulavasti tunteesta toiseen ja esittelemällä samalla uuden teoksen. Analyysin seuraamista helpottaa myös se, että Rossi palaa aika ajoin aiemmin analysoituihin teoksiin pitämällä näin laajan kokonaisuuden koherenttina, itseensä viittaavana systeeminä.

Folkloristina luin primitivismiä varsin tuttuna ilmiönä: monella tapaa voidaan sanoa, että koko folkloristiikan tieteenala peilautuu primitivismin kaltaisen kansallisromanttisen menneisyydenkaipuun värittämien linssien läpi (vrt. Anttonen 2005). Ymmärrän Rossin tulevan vankasti kirjallisuudentutkimuksen piiristä, mutta jäin silti kaipaamaan enemmän keskustelua kansanrunouden- ja 
perinteentutkimuksen suuntaan: ei liene ylimitoitettua väittää, että nimenomaan folkloristiikka (tai silloinen suomalainen ja vertaileva kansanrunoudentutkimus) on ollut eräs merkittävimmistä primitivismiin ja kirjallisuuteen vaikuttaneista humanistisista tieteenaloista Suomen alueella, Rossin tarkkanäköisesti erittelemän antropologian ohella. Rossi sivuaa kansanperinteeseen, kansanuskoon ja kalevalamittaisiin runoihin liittyviä teemoja esimerkiksi Lehtosen Putkinotkon ja Ahon Panun kohdalla, mutta kytkökset näihin jäävät kursorisiksi. Tutkimus syvenisi näiden teemojen kohdalla esimerkiksi kansanuskon ja -tapojen (Apo 1995), kansanrunouden keruun ja yhteiskunnan suhteen (esim. Siikala 2012, 27-50), kansa-käsitteen problematiikan (Hämäläinen et al. 2020), moderni/perinne-dikotomian (Anttonen 2005) sekä karelianismin (Anttonen 2005; Sihvo 1973) tarkastelulla. Lisäksi tyyliseikkojen analyysi kuten esimerkiksi Rossin mainitsema kansankielinen rekisteri (s. 114) voisi saada vielä lisää tulta alleen nimenomaan folkloristiikan tutkimuksia sivuamalla.

Tämän lisäksi jäin mietiskelemään luonnon käsitteen monimutkaisuutta ja sen roolia Rossin tutkimuksessa. Luonto, sen suhde primitivismiin ja samastaminen tunteisiin kulkevat läpi teoksen yhtenä punaisista langoista, mutta nämä olisivat silti voineet saada hieman enemmän tilaa tutkimuksessa. Tulevissa tutkimuksissa lukisin mieluusti vielä lisää analyysia primitivismin luontokokemuksesta, subliimista, maisemasta ja näiden affektiivisuudesta - aiheessa olisi ainesta myös monitieteiseksi kokonaisuudeksi, jossa voisi saada tilaa vaikkapa visuaalisen suhde kirjalliseen. Subliimi, maisema, luonto ja primitivismi keskustelevat tiiviisti esimerkiksi taidehistorian ja maisemantutkimuksen käsitteiden ja analyysien kanssa (esim. Häyrynen 2005).

Kaiken kaikkiaan Rossin tutkimus on hieno kokonaisuus, joka tarjoaa mahdollisuuksia monenlaiseen tieteidenväliseen keskusteluun. Affektiivisuutta voisi juuri nyt kuvailla suorastaan muodikkaaksi käsitteeksi, mutta Rossi selviää valtavan ja osin usein hämäräksikin jäävän käsiteverkoston vuosta varsin mallikkaasti pysymällä primitivismin ja kirjallisuudentutkimuksen ja näiden tarjoamien affektiivisuuskeskustelujen piirissä. Rossin tutkimusta voisi hyvin pitää esimerkkitapauksena siitä, miten "tunteita" (sana kattaa Rossin käsittelytavassa väljästi sekä emootiot että affektit) voi lukea analyyttisesti erilaisista diskursiivisista aineistoista. Aineistojen ei välttämättä tarvitse olla kirjallisuutta yhtä lailla vaikkapa muistitieto- tai haastatteluaineistoihin voisi soveltaa Rossin tapaista tunteiden poetiikan analyysia.

Teos on myös osoitus siitä, että niin sanottuja "kansallisen kaanonin" kulmakiviä on mahdollista tutkia ilman kansallisen pönkittämistä tai toisaalta ilman sen ylitsevuotavaa kritiikkiä. Rossi sopeuttaa analysoimansa kirjalliset teokset luontevasti osaksi ylirajaisia kirjallisuuden virtauksia, ja säilyttää sopivan maltillisen, mutta aihettaan myös lämpimästi tarkastelevan analysoijan äänen läpi tutkimuksen.

Heidi Haapoja-Mäkelä 


\section{Kirjallisuus}

Anttonen, Pertti 2005. Tradition through Modernity: Postmodernism and the Nation-State in Folklore Scholarship. Studia Fennica Folkloristica 15. Helsinki: SKS.

Apo, Satu 1995. Naisen väki: Tutkimuksia suomalaisten kansanomaisesta kulttuurista ja ajattelusta. Helsinki: Hanki ja jää.

Hämäläinen, Niina, Kati Mikkola, Ilona Pikkanen \& Eija Stark 2020. Miten kansasta tulee vernakulaari? Kansanrunoudentutkimuksen, kirjallisuushistorian ja kansankirjoittajien tutkimuksen kansakuva 1820-luvulta 2010-Iuvulle. Elore 27(1), 37-59. DOI: 10.30666/elore.89069.

Häyrynen, Maunu 2005. Kuvitettu maa: Suomen kansallisen maisemakuvaston rakentuminen. Suomalaisen Kirjallisuuden Seuran Toimituksia 834. Helsinki: SKS.

Sihvo, Hannes 1973. Karjalan kuva: Karelianismin taustaa ja vaiheita autonomian aikana. Väitöskirja. Suomalaisen Kirjallisuuden Seuran Toimituksia 314. Helsinki: SKS.

Siikala, Anna-Leena 2012. Itämerensuomalaisten mytologia. Suomalaisen Kirjallisuuden Seuran Toimituksia 1388. Helsinki: SKS. 